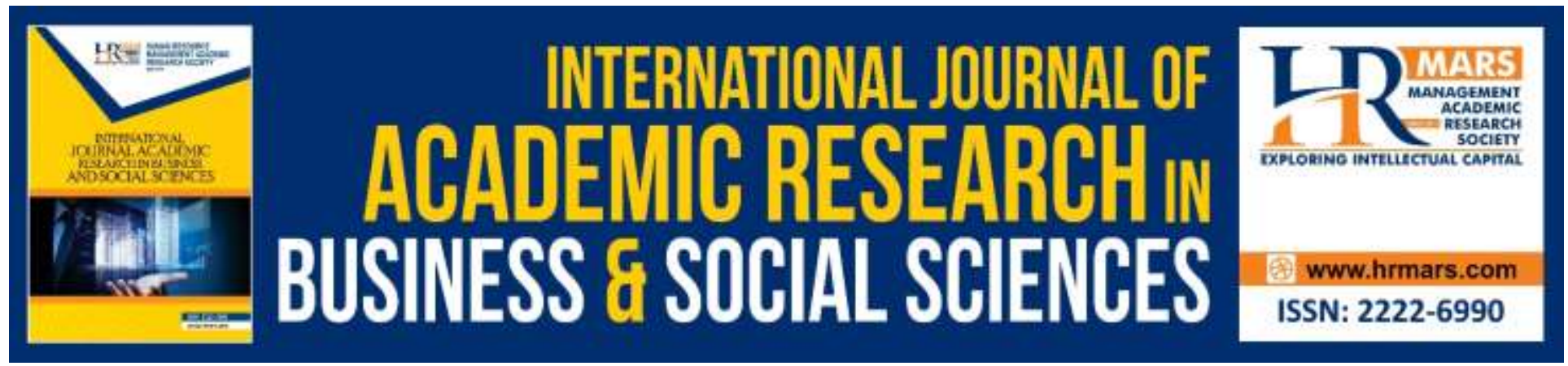

\title{
Concept of Wages from Islamic Scholars Perspectives
}

\author{
Noor Azira Aina Binti Mohd Azizudin, Wan Khairul Aiman Wan Mokhtar
}

To Link this Article: http://dx.doi.org/10.6007/IJARBSS/v9-i11/6584

DOI: 10.6007/IJARBSS/v9-i11/6584

Received: 29 September 2019, Revised: 18 October 2019, Accepted: 14 November 2019

Published Online: 27 November 2019

In-Text Citation: (Azizudin, Mokhtar, 2019)

To Cite this Article: Azizudin, N. A. A. B. M., Mokhtar, W. K. A. W. (2019). Concept of Wages from Islamic Scholars Perpectives. International Journal of Academic Research in Business and Social Sciences, 9(11), 633639.

Copyright: (C) 2019 The Author(s)

Published by Human Resource Management Academic Research Society (www.hrmars.com)

This article is published under the Creative Commons Attribution (CC BY 4.0) license. Anyone may reproduce, distribute, translate and create derivative works of this article (for both commercial and non-commercial purposes), subject to full attribution to the original publication and authors. The full terms of this license may be seen at: http://creativecommons.org/licences/by/4.0/legalcode

Vol. 9, No. 11, 2019, Pg. 633 - 639

http://hrmars.com/index.php/pages/detail/IJARBSS

JOURNAL HOMEPAGE

Full Terms \& Conditions of access and use can be found at http://hrmars.com/index.php/pages/detail/publication-ethics 


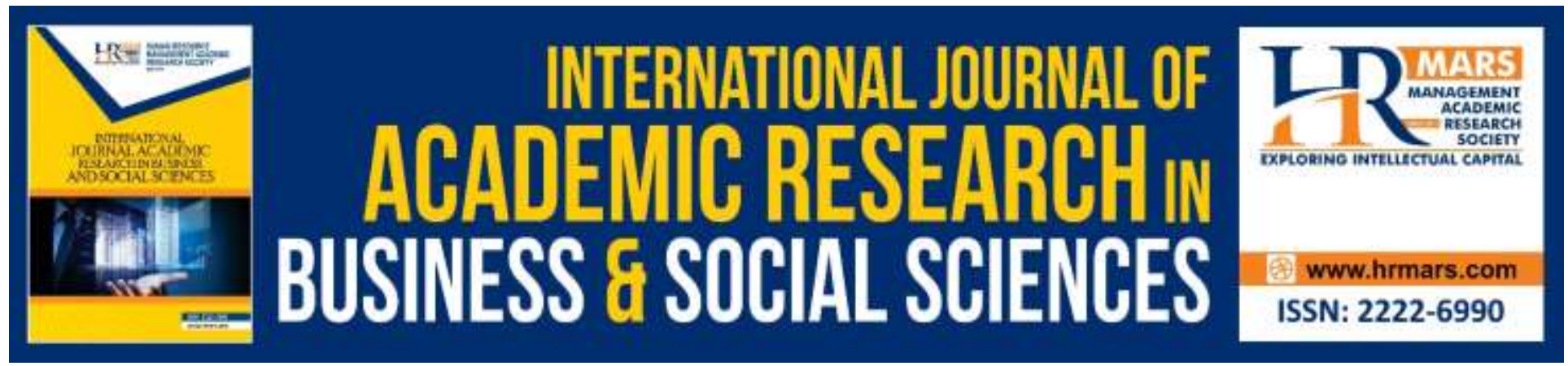

\title{
Concept of Wages from Islamic Scholars Perspectives
}

\section{Noor Azira Aina Binti Mohd Azizudin, Wan Khairul Aiman Wan Mokhtar}

Universiti Sultan Zainal Abidin (UniSZA), Gong Badak Campus, 21300, Kuala Nerus, Terengganu, Malaysia

\begin{abstract}
The purpose of this study was to determine, identify and analysing the view of the scholars on the concept of wages (ujrah). The scholars have a different opinions regarding the wages (ujrah) in Fiqh perspective. This method of Ujrah is the best part of Fiqh perspectives that is to identify, classify and analyse the information of that relating to the identify topic of discussion. This method used a few of methods in issuing. With the methods of Conventional Research Methodology (CRM), techniques used to collect and analyse data of Fiqh perspective according to the source of islamic jurnals and article from internet. This topic is referred to some opinions from others. The another method adopted in this discussion regarding with Islamic primary sources and Islamic secondary sources. The question arises about the situation are, what is the definition of Ujrah in islam? What are the kind of relevant approaches to be implemented in analyse the detail about the issues of Ujrah from Fiqh perspective in islam and within muslims? What is conditions of Ujrah practice in Fiqh perspective including examples. To answer these questions, this study has a few of objectives. The objectivity of this assignment is to expose to all the judicial laws relating to the selected title and the proposition support of the Al-Quran AlKarim or the authentic hadiths of the Rasulullah S.A.W. This task contains the views of scholars to the concept of wages. Some of the important things that describe the concept of wages (ujrah) are detailed in terms of definition, law in Islam, certain terms, examples and related terminals and conclude with the whole formula of the concept of wages (ujrah). First, it is purpose done to recognize the concept of Ujrah from Fiqh perspective, secondly, to identify the meaning of Ujrah in islam, and to analyse and formulate a wage law and the rule of law wage practice in concept of wages that study of Ujrah in Fiqh perspective. This qualitative study uses contents analysis for the aim of analyse data collected. Through this approach, considered best suited to be implemented in the concept of wages (ujrah in figh perspective).
\end{abstract}


Keywords: Ujrah, fiqh, Islamic research-Based, Scholars

\section{Introduction}

Islamic economic is a science that examines human behavior in the matter of using and managing natural resources for the benefit of the community as well as for the pleasure of Allah. Human life cannot escape the practice of maintaining good relations between people and relationships with the universe.

Based on God's word S.W.T it is clear that human life should help each other. As well as the relationship between employers and their employees in various sectors including administration, industry, agriculture, fisheries, education and others. The main goal of one's work is to get the wages to meet the basic needs by not taking into account the economic or political factors of a country. Accordingly, the wage setting of workers should be made in a proper and fair context in order not to negatively affect the economy of the country. Changes in wages can affect the rates of intake, purchasing power, and their living standards.

The questions; what is the definition of ujrah? What is the kind of relevant approaches to be implemented in analyse the information about the issue of ujrah from fiqh perspective in islam and within muslims? What is the conditions of ujrah practice in fiqh perspective including examples.

Discussion of collect and analyse the data based on hadith is very important to carry out. Therefore, it is more important to identify the best method can be approach in realizing the mentioned technique above. Hence, this study was conducted for three purposes; first, to identify the concept of wage in fiqh perspective. Second objective is analyzing the information regarding the issue of ujrah. The last one is expose to all the conditions of ujrah relating to the selected title and the proposition support of the Al-Quran Al-Karim or the authentic hadiths of the Rasulullah S.A.W.

In general, the research papers are divided into two category. The first part is the discussion of wages concept; secondly, the expose to all the conditions concept of wages (ujrah) involved Islamic primary source.

\section{Research Methodology}

To achieve the goal of this study, qualitative research has been used. Then, this study focuses on explore and descriptive research. In addition, data collected through library research and internet research as a data collection tool. Data were analysed using content analysis method (Mokhtar, 2017; Mottan \& Shanmugam, 2018). 


\section{Findings and Research Discussion Ujrah from Fiqh Perspective}

Humans are a kind of Creatures created by Allah S.W.T where it cannot live alone, it requires cooperation and help in order to make ends meet. So between forms cooperation and assistance between one another through Uqud Mu'awadhat (aqad exchange) is through wages, which in fiqh is called Ajr or Ujrah.

Ujrah is mentioned in the Al-Quran Karim and Al-Sunnah which is the Al-Quran Karim and AlSunnah catch Ujrah as a duty of the musta'jir (tenant) who must give wage payments to mu'ajir fully for the employment or services rendered, whereas mu'ajir must do the job or service as well, the failure to meet these conditions is considered a failure moral both from the musta'jir and mu'ajir and this must be accounted for answer to God. Accordingly, the fuqaha has outlined one the method that everything can be made as a price payment in aqad then buy it can be used as a rental payment (Ujrah) (Ibn-Qudamah, 1994).

\section{Definition of Ujrah}

Humans are created by Allah SWT as an unlucky create a live alone without the help of others, one form Human activities in the scope of the mammal are wages-hired, the in the Islamic fiqh called ujrah. Ujrah (wage) is a reward or consideration of the benefits it earns (Syafe'i, 2004).

According to Hanafiah, Ujrah is an agreement to enable ownership known and deliberate benefits of a material leased with reward (Suhendi, 2005). According to Shaykh Syihab al-Din and Shaykh Umainas Ujrah is agreement on the known and deliberate benefits to grant and allowing for a known reward at that time.

Based on the above definition, it is understandable and when translated in malay means wageshire is selling energy or strength. More precisely the concept of Ujrah or al-Ujr wa al-umulah itself can be defined as compensation promised and paid by service cutter as a treasure for the benefit it enjoys. Ujrah value which should be clearly stated in accordance with the hadith of the prophet. Refers to most Ulama definitions when defining ljarah it is found that they use the word 'Iwadh (wage payment) as it is it is clear in the first part (Al-Fairuz-Abadi, 2003 \& Ibn-Manzur, 1990). And there are also Ulama who give understanding Ujrah itself is:

Meaning: Wages on Benefit.

Where Majallah Ahkam Adliah defines Ujrah as: 
Which means: replacement (payment) on Benefit.

From the definition of the definition it can be concluded that Ujrah is a wages paid by tenants (beneficiaries of either 'ayn or employment) to the lessor (beneficiary whether 'job or job') over the benefits it finds.

\section{Issues of Ujrah Issue in Fiqh Perspective Ujrah should know its level or type clearly}

Fuqaha agrees that ujrah must have known the rate clearly in the form of naqd (cash), 'ayn (goods) or benefits.

\section{Ujrah in the form of naqd (cash) and 'ayn (goods)}

Ulama agrees that the origin of ujrah is in the form of naqd (cash) and also be used as a ujrah provided that the parties must explain the ujrah rate is as described above (Al-Sarakhsi, 1994).

\section{Ujrah in the form of benefits}

Ulama agrees that Ujrah can be approved in the form of Benefits and Ulama the Hanafi sect requires that Ujrah in the form of Benefits be different from the benefits of ijarah, because it brings to usury. Anytime Jumhur Ulama from the Mazhab Maliki, Shafi'i and Hambali also require and abolish even even the type of manfat Ujrah is the same as the type of benefits ljarah (AlHaskafi, 1992).

\section{Ujrah in the form of nafqah}

Ulama agrees that Ujrah in the form of nafqah either with cash or things in the darkness of the jade if it is clear to the nafqah. Even if it does not explain the level then Jumhur Ulama Mazhab Hanafi, Shafi'i, and one riwarah from Hambali cites illegitimately because it contains elements Jahalah (uncertainty) (Al-Sarakhsi, 1994). According to the Mazhab Maliki and a rulayah from The Hambali school is legitimate although it is unclear at its level and can be known on the basis to customs custom (Al-Mauwaq, n.d.).

\section{Ujrah in the form of Hissah (specific parts or ratios) of the product or work}

Jumhur Ulama the Hanafi, Maliki and Shafi'i schools are of the opinion that void Ujrah in the form of Hissah (specific parts or ratios) of the product or work ijarah tersebut (Al-Sarakhsi, 1994). While the Hanabi School considers that Ujrah is valid in Hissah form (specific part or ratios) of the award or employment of the ijarah. (Al-Buhuti, 1982).

\section{The Conditions of Ujrah}

In Islamic law arrange a number of requirements related to ujrah as follows: 
Firstly, Ujrah (wages) should be performed in ways of deliberation and open consultation, so that it can be realized within each individual economic actors, high moral obligations and loyal dedication to public interest. Secondly, wages should be mal mutaqawin and the wage should be clearly stated (Mas'adi, 2002). Concrete or by mentioning the criterion. Since wages represent payments on the value of benefits, the value it is necessary to be known clearly. Hiring people with wages, are examples of vague wages because it contains the jihalah element (uncertainty). Then, wages should be different from the type of object. Hired a jobs with similar jobs, are examples that do not meet these requirements. Therefore, the law is invalid, because it can deliver on the practice of riba (Ibid). For example employing a portrait to build a house and its wages building material or home. Lastly, the rental agreement must not be a benefit of the type something that made the agreement and illegally helped someone with wages helping others. The problem is not valid because equality of benefit type, then each is obliged pay wages or fees as soon as possible after using the person's energy (Al-Jaziri, 1994).

The scholars allow to take wages in return from his job, because that is the right of a worker to get the reward they deserve. The scholars have been set the wage requirements such as permanent fixed assets and it should not be the same as the benefits of reward, like wages tenant of the house to occupy by occupying the house. (Syafe'i, 2004; Liazos \& Markati, 2018).

The determination of wages in Islam is based on work or the benefits of a person's workforce. In Islam Job professionalism is highly appreciated for the wages of a worker really based on the expertise and benefits provided by the employee (Al-Suyuti, n.d.). Basic requirements in the Quran and as-Sunnah on The hired thing is that the magicians should give wages to the muhajir entirely for the services rendered, while the fees should be made the best of work, the failure to meet these requirements is regarded as a moral failure both of the authorities as well as money and this should be accountable to God (Ibid).

\section{Conclusion}

Based on the what we discuss above, concept of wage (ujrah) give a justice to all of employee. In my opinion, following and emulating the concept of wages in islam is very important for every human being as it can be used in our lives. In addition, through this concept, human beings can carry out their daily needs according to the demands or correctness of the Islamic syariah as Islam is a complete religion of every aspect of life beyond the other religions and gives the benefit to mankind itself (Baim, 2013; Muthoka, Oluoch, Muiruri, 2018).

\section{Acknowledgement}

This paper is founded on the research project of the Fundamental Research Grant Scheme FRGS/1/2018/SSI03/UNISZA/02/2 (Project No: RR279). Special appreciation is owed to Ministry of Higher Education Malaysia (MOHE) and Universiti Sultan Zainal Abidin (UniSZA) for sponsoring and supporting this research. 
INTERNATIONAL JOURNAL OF ACADEMIC RESEARCH IN BUSINESS AND SOCIAL SCIENCES

Vol. 9, No. 11, November, 2019, E-ISSN: 2222-6990 @ 2019 HRMARS

\section{Corresponding Author}

Wan Khairul Aiman bin Wan Mokhtar (Ph.D), Senior Lecturer, Universiti Sultan Zainal Abidin (UniSZA), Kampus Gong Badak, 21300 Kuala Nerus.

E-mail:wk_aiman@yahoo.com / wkhairulaiman@unisza.edu.my

\section{References}

Al-Buhuti. (1982). Kashaf al-Qina'. Beirut: Dar al-Fikr.

Al-Fairuz-Abadi. (2003). Al-Qamus al-Muhit. Beriut: Muasasah al-Risalah.

Al-Haskafi. (1992). al-Dur al-Muhtar Hashiyah Rad al-Muhtar. Beirut: Dar al-Fikr.

Al-Jaziri, A. (1994). Fiqh Empat Madzab (Al-Fiqh' Alal Madzah ibil Arba'ah), Juz IV. Semarang: CV As-Syifa'.

Al-Mauwaq (n.d.). Al-Taj wa al-Iklil bi Hamish Mawahib al-Jalil. Beirut: Dar al-Ma'rifah.

Al-Mawardi. (1994). Al-Hawi al-Kabir. Beirut: Dar al-Kutub al-Ilmiah.

Al-Quran Al-Karim.

Al-Sarakhsi. (1986). Al-Mabsut. Beirut: Dar al-Ma'rifah.

Al-Suyuti. (n.d.). Al-Jamius Sagir, Juz II. Darul Fikr.

Baz, R. (1993). Sharh Al-Majallah. Beirut: Dar al-Kutub al-Ilmiah.

Ibn-Manzur. (1990). Lisan al-Arab. Beirut: Dar Sadir.

Ibn-Qudamah. (1994). al-Mughni. Beriut: Dar al-Fikr.

Liazos, N. \& Markati, D. (2018). Difficulties in Learning Turkish as a Second Language by Greekspeaking Students: A teaching model. Multilingual Academic Journal of Education and Social Sciences, 6(1), 149-162 (in Greek).

Mas'adi, G. (2002). Fiqh Muamalah Konstektual. Jakarta: PT. Raja Grafindo Persada

Mokhtar, W. K. A. W. (2017). Concept Al-Hadīth Al-Mawḍū'iy as A Method of Collecting and Analyzing Research's Data. International Journal of Academic Research in Business and Social Sciences, 7(2), 536-542.

Mottan, K., \& Shanmugam, D. (2018). Role of Parents in Remedial Pupil's Academic Achievement. International Journal of Academic Research in Progressive Education and Development, 7(4), 166-178.

Muthoka, N. I., Oluoch, O., Muiruri, P. M. (2018). The Influence of Branchless Financial Innovation on Market Capitalization of Commercial Banks Listed in NSE, Kenya, International Journal of Academic Research in Accounting, Finance and Management Sciences 8 (4): 120-130.

Qadir, A. (1992). Al-Wasit fi Aqd al-ljarah fi al-Fiqh al-Islami. Cairo: Dar al-Nahdhah al-Arabiah.

Suhendi, H. (2005). Fiqh Muamalah. Jakarta: PT. Raja Grafindo Persada.

Syafe'i, R. (2004). Fiqh Muamalah. Bandung, Pustaka Setia. 